\title{
Proje Yönetimine Kurumsal Bir Yaklaşım: Jandarma Genel Komutanlığına Özgü Yeni Bir Proje Yönetim Modeli
}

\author{
An Institutional Approach to Project Management: \\ A New Project Management Model Specific to \\ the Gendarmerie General Command
}

\author{
Erdem ERCIYES ${ }^{\star}$ - Erdem ÖZGÜR ${ }^{\star \star}$
}

\begin{abstract}
$\ddot{O} z$
Bu çalısmanın amacı, Fandarma Genel Komutanlı̆̆na özgülenebilecek bir proje yönetim sistemi oluşturmaktrr. Çalısmanin temel araşttrma sorusu "Fandarma Genel Komutanlı̆̆ına özgü proje yönetimi yaklaşımı nasıl olmalıdır?”. Bu soruya cevap bulabilmek için çalısmada etnografik bir araştrrma metodolojisi benimsenmiştir. Aymca araştırma metodu olarak Fandarma Genel Komutanlğ̆nda proje faaliyetleri icra eden dokuz personelle yar yapilandirlmıs mülakatlar ve ikincil bilgi kaynă̆ olarak literatür (dizin) taraması yapılmıstır. Fandarma Genel Komutanlı̆̆nın proje yönetim sisteminde etkinliğin sağlanabilmesi için atılması gereken en önemli adım olarak ihtiyacı doğru olarak tantmlayabilen, proje yapan, yapttran, yöneten ve kontrol eden bir Arasttrma Gelistirme Merkezinin kurulması tespit edilmiştir. Çalısmanin sonunda Fandarma Genel Komutanlığının proje yönetim sürecine özgü yeni proje yönetim modeli olusturulmustur.
\end{abstract}

Anahtar Kelimeler: Proje Yönetimi, Proje Süreçleri, Kolluk Yönetimi, Fandarma Genel Komutanlı̆̆, Ar-Ge.

\section{Abstract}

This research aims to develop a project management system that can be customized to the Gendarmerie General Command. The main research question of the study is "How should

\footnotetext{
* Dr. Personel Albay, Jandarma Genel Komutanlığı Strateji Başkanlığı, Ankara, Türkiye, ORCID: 0000-0002-7842-0967, e-posta: erdemerciyes@yahoo.com.

*夫 Dr. Jandarma Albay, Jandarma ve Sahil Güvenlik Akademisi Başkanlığı, Ankara, Türkiye, ORCID: 0000-0002-1403-4442, e-posta: eozgur76@ hotmail.com.
}

Geliş Tarihi / Submitted: 02.06.2020

Kabul Tarihi / Accepted: 28.02.2021 
be the project management approach specific to the Gendarmerie General Command?" In order to find a response to this question, an ethnographic research methodology was followed in the study. In addition, as a research method, semi-structured interviews were conducted with nine personnel who have been carrying out project activities at the Gendarmerie General Command and literature review was performed as a secondary source of information. The establishment of a Research and Development Center who can accurately identify needs, conduct, manage and control projects, has been determined as the most important step to be taken to ensure effectiveness in the project management system of the Gendarmerie General Command. At the end of the study, a new project management model specific to the project management process of the Gendarmerie General Command has been established.

Keywords: Project Management, Law Enforcement Management, the Gendarmerie General Command, Research and Development.

\section{Giriş}

Jandarma Genel Komutanlığı kamu düzeni ve güvenliğini sağlamak üzere kendi sorumluluğuna verilmiş alanlarda, Türkiye geneline yayılmış bir şekilde faaliyet icra eden bir kolluk kuvvetidir. Günümüzde iç ve diş güvenliğin geldiği nokta ve yaşanan her olayın altında bir güvenlik meselesi olduğu dikkate alındığında, ülkelerin kendi güvenliklerini sağlamak için sosyal, demografik ve ekonomik yapıları kapsamında savunma plan ve harcamalarında ${ }^{1}$ ciddi oranlarda payı olan Jandarma Genel Komutanlığının sürekli kendini yenileyen ve geliştiren bir vizyonda hareket etmesi, proaktif bir bakış açısı sergilemesi ve ortaya çıkan durumlara hızlı reaksiyon gösterebilmesi büyük önem arz etmektedir.

Jandarma Genel Komutanlığının mevzuatla belirlenmiş olan görevlerini doğrudan ve dolaylı olarak etkileyen kurumsal gelişim faaliyetleri ile Araştırma ve Geliştirme (Ar-Ge) ve Savunma Sanayi Başkanlığı projelerinin yönetim sürecinin işletilmesinin ana sorumluluğu hali hazırda Jandarma Genel Komutanlığı Strateji ve Dış İlişkiler Başkanlığına bağlı Proje Yönetim Şube Müdürlüğü tarafından yürütülmektedir. Ancak uygulamada birimler üst yönetimin onayını alarak kendileri proje başlatıp yürütebilmektedir. Birçok organizasyonda da rastlanıldığı şekilde birbirinden bağımsız şekilde yürütülen projeler, kurumların gelişime

${ }^{1}$ Salih Aygün and Tolga Öz, "The Effects of Defence Expenditures on Growth: The Case of Turkey", Fournal of Defense Resources Management, 2020, 11(2 (21)), p.7. 
Proje Yönetimine Kurumsal Bir Yaklaşım:

Jandarma Genel Komutanlığına Özgü Yeni Bir Proje Yönetim Modeli

yönelik bütüncül bakış açısını ihtiva etmediği zaman, kurumun vizyonunun gerçekleştirilmesine yönelik gayret birliği oluşmasına engel olabilmektedir. Benzer projeler veya birbirinin devamı olması gereken süreçler her birim ve her proje ekibi tarafından ayrı ayrı işletilebilmekte, karşılıklı iş birliği sorunları yaşanabilmekte ve nihayetinde tamamlanamamıs veya maliyetetkin sonuçlandırılamamış projelerle karşılaşılabilmektedir. Geçmiş dönemde kamuoyuyla da paylaşılan ve silahlı kuvvetler bünyesinde yürütülen personel yönetim sistemine ilişkin projelerin beklenen sonuca ulaşamaması gayret birliği eksikliğine örnek teşkil etmektedir. Bu bağlamada önemli bir nokta da cari hizmet yürüten birimlerin proje yönetim süreçlerini bir yük olarak görebilmesidir. Bürokratik süreçlerin yoğunluğu ve süreli işlemlerin zamanında bitirilme gerekliliği, proje süreçlerini aksatabilmekte veya süreç takibini zorlaştırabilmektedir.

Bu çalışmanın amacı, Jandarma Genel Komutanlı̆̆ına özgülenebilecek kolluk görev alanına giren farklı projelerin benzer yöntemlerle yönetilmesini sağlayarak, projeleri; izlenebilir, kontrol edilebilir, yönetilebilir hale getirecek ve birbiri arasında eşgüdümü sağlayacak bütüncül bir proje yönetim sistemi geliştirmektir. Çalışmanın temel araştırma sorusu "Jandarma Genel Komutanlığına özgü proje yönetimi yaklaşımı nasıl olmalıdır?” Bu soruya cevap bulabilmek için çalışmada kurum proje yaklaşım kültürünü ortaya koyması nedeniyle etnografik bir araştırma metodolojisi benimsenmiştir. Ayrıca araştırma metodu olarak Jandarma Genel Komutanlığında proje faaliyetleri icra eden personelle yarı yapılandırılmış mülakatlar ve ikincil bilgi kaynağı olarak literatür (dizin) taraması yapılmıştır. Böylelikle teori ve uygulamanın örtüştürülmesi neticesinde sahanın ihtiyaçlarına cevap verebilecek aynı zamanda kuramsal derinliği olan kuruma özgülenebilecek bir model oluşturulabileceği değerlendirilmektedir.

\section{Literatür Taraması}

İnsanlık tarihi boyunca küçügünden büyügüne türlü türlü proje yönetilmiş ve icra edilmiştir. Ancak proje yönetiminin bilimsel bir disiplin olarak ortaya çıkmasında İkinci Dünya Savaşı sırasında Amerika Birleşik Devletleri tarafından başlatılan Manhattan Projesi² önemli bir rol

\footnotetext{
${ }^{2}$ Manhattan Projesi, İkinci Dünya Savaşı sırasında ABD'de atom bombası üretmek üzere başlatılan toplamda 600,000 'den fazla kişinin görev aldığı ve sonuçları (Alex Wellerstein,
} 
oynamış ve proje süreçleri bilimsel bir formatta tanımlanmıştır ${ }^{3}$. Aslında yapılan her işin bir proje olamayacağını da ortaya koyan, yeni ürün geliştirme ve inovasyonun stratejik tasarım performansı gerektirdiğini belirten Lenfle, yöneticilerin bu süreçteki kaygılarını proje yönetiminin gidereceğini savunmaktadır. Çünkü proje yönetiminin temelinde, hedefleri belirli olsa da bu hedeflere nasıl ulaşılacağı ve sonuçlarının ne olacağı belirli olmayan bir işi öngörülebilir yapmak vardır. Devamında ise özellikle 1950’lerde büyük askerî projelerin belirsizlikleri üzerinden geliştirilen eski ve yeni sistemin belirli bir süre beraber çalıştığ 1 paralel yaklaşım stratejisi ile birden fazla alternatifin bir arada geliştirilmesiyle riskleri azaltma ve en iyiyi seçme imkânı sağlama proje yönetiminde ana yaklaşım olarak benimsenmiştir ${ }^{4}$. Bu yaklaşımın günümüzde de etkisinin olduğunu söylemek mümkündür.

$\mathrm{Bu}$ noktada projenin ne olduğu ve olmadığının ayırımının net olarak yapılması gerekmektedir. Proje; belirli kaynaklarla, özgün ürün, hizmet veya sonuç gerçekleştirmek için yürütülen geçici bir çalışmadır ${ }^{5}$. Ana özellikleri olarak; tesis edilmiş bir amaç, başı ve sonu olan tanımlanmış bir zaman dilimi, farklı birimlerin koordinasyonu, daha önce yapılmamış ve sonucu tam olarak öngörülemeyen bir şeyi gerçekleştirme hedefi ve belirli kaynak, maliyet ve performans istekleri ön plana çıkmaktadır. Projenin ne olmadığı anlamak için sorulması gereken temel soru ise; yapılmak istenen çalışmanın rutin ve tekrar eden bir iş olup olmadığıdır ${ }^{6}$.

Projenin tanımını ortaya koyduktan sonra proje yönetimi kavramına doğrudan geçmeden önce proje sürecinin odak noktasında yer alan proje

\footnotetext{
"How many people worked on the Manhattan Project? Restiricted Data": The Nuclear Secrecy Blog. http://blog.nuclear.secrecy.com/2013/11/01/many-people-worked-manhattanproject/. (Erişim Tarihi 31 Mart 2020).) itibariyle tarih en yıkıcı çalışmalarından birisidir. Projenin çıktısı olan atom bombasının ABD tarafından Hiroşima ve Nagasaki'ye atılması sonucu yüzbinlerce kişi ölmüş ve İkinci Dünya Savaşı bitmiştir.

${ }^{3}$ Sylvain Lenfle "The Strategy of Parallel Approaches in Projects with Unforeseeable Uncertainty: the Mahhattan Case in Retrospect", International Fournal of Project Management, 2011, 29 (4), p. 359-373.

4 K. Artto, J. Kujala, P. Dietrich, M. Martinsuo, "What is project strategy?", International Fournal of Project Management, 2008, 26 (1), p. 4-12.

5 Eric W. Larson, Clifford F. Gray, Project Management: The Managerial Process, McGraw-Hill Education, Sixth Ed., New York, 2014, p. 6.

${ }^{6}$ A.g.e., p. 7.
} 
Proje Yönetimine Kurumsal Bir Yaklaşım:

Jandarma Genel Komutanlığına Özgü Yeni Bir Proje Yönetim Modeli

yöneticisinin tanımını ortaya koymada fayda bulunmaktadır. Bu konuda en fazla kabul gören tanımlardan birisi Mesleki Yeterlilik Kurumunun yaptığı tanımdır:

"Proje Yöneticisi (Seviye 6), projenin gereksinim, risk/firsat ve paydaş çözümlemesinin yapılmasın sağlayarak proje yürütme planını hazırlanmasın sağlar; proje yürütme planı çerçevesinde proje faaliyetleri ile ilgili satın alma ve sözleşme yönetimi gibi iş organizasyonu faaliyetlerini gerçekleştirerek proje uygulama faaliyetlerini başlatır; proje ekibini ve iletişim faaliyetlerini yöneterek projenin ilerleme ve sonuçlanma durumunun takibini yapar. Proje Yöneticisi (Seviye 6), çalışmalarnı iş sağllğ ve güvenliği ile çevre koruma önlemleri ve kalite gereklilikleri çerçevesinde gerçekleştirir ve mesleki gelişimine ilişkin faaliyetlerde bulunur."

$\mathrm{Bu}$ tanımdan hareketle, proje yöneticisinin yürütülen projeye göre belirli seviyede teknik bilgiye sahip olması da önemli bir kıstastır. Ancak proje yöneticisi ifadesi ebedi bir tabir değildir ve bir mesleği ya da statüyü anlatmamaktadır. Bir projede yönetici olan bir kişi başka bir proje de yürütücü8 olabilmektedir. Ayrıca proje yöneticisine ilave olarak projenin yapılmasına karar verilmesi aşamasında talep yöneticisi ihtiyacın doğru olarak değerlendirilmesinde önemli bir role sahiptir. Proje aşamasına geçildiğinde portföy yöneticisi, ${ }^{9}$ projenin mali durumunu, risk beklentilerini ve gerçekleşme durumunu takip ederek ilgili birimler arasında eşgüdüm sağlamaktadır.

\footnotetext{
7 “Ulusal Meslek Standardı: Proje Yöneticisi Seviye: 6", Mesleki Yeterlilik Kurumu, 2018, s. 6.

${ }^{8}$ Proje yürütücüsü, ilgili bilim alanında gerekli uzmanlığa ve proje hazırlama ve yürütme yetkinliği ve deneyimi olan, projenin bilimsel, teknik, idari, mali ve hukuki her türlü sorumluluğunu taşıyan ve proje sözleşmesini imzalayan, proje sonuçlarını bilimsel yöntemlerle değerlendirip yayımlayabilen kişi veya kişilerdir (1003-Öncelikli Alanlar Ar-Ge Projeleri Destekleme Programı Usul ve Esasları, https://www.tubitak.gov.tr/tubitak_content files/mevzuat/esaslar/204BK-EK.pdf, (Erişim Tarihi: 22 Mart 2021).). Proje yöneticisi ise projeyi teklif eden ve genel sorumluluk üstlenen, bazı durumlarda farklı kurum/kuruluşlarda yürütülen alt projelerden oluşan orta ve büyük ölçekli projelerde, proje yürütücüleri arasında koordine sağlayan ve projenin yönetiminden sorumlu kişi ya da kişileri tanımlamaktadır (1003-Öncelikli Alanlar Ar-Ge Projeleri Destekleme Programı Usul ve Esasları, https://www.tubitak.gov.tr/tubitak_content_files/mevzuat/esaslar/204BK-EK.pdf, (Erişim Tarihi: 22 Mart 2021)). Bu nedenle iki kavram farklı olarak kullanılmaktadır/kullanılmalıdır.

${ }^{9}$ Proje portföy yöneticisi, projenin finansal girdi ve çıktılarını ortaya koymak ve analiz maksadıyla proje yönetim organizasyonları tarafından gerçekleştirilen süreçten sorumlu kişi ya da kişilerdir. Temelde karar etki ettiği nokta yeni proje yatırımlarının maliyet
} 
Projelerin karmaşık ve kısıtlarla örülü dinamik yapısından dolayı, proje yöneticilerinin ve yürütücülerinin belirli bir yaklaşım takip etme ihtiyaçları bulunmaktadır. Bununla ilintili olarak hâlihazırda farklı amaçlara ve sektörlere hitap eden öngörülü (predictive) ve çevik (agile) olarak sınıflandırılan iki ana proje yönetim yaklaşımı bulunmaktadır. Öngörülü proje yönetimi yaklaşımları bir sürecin tüm aşamalarının bir sırayla gerçekleştiği doğrusal bir yaklaşımdır. Yöntemin uygulanabilmesi için proje yönetici ve yürütücüleri öngörülebilir araçlara ve deneyime sahip olmalıdır. $\mathrm{Bu}$ yaklaşım geleneksel proje yönetim özellikleri taşımakta ve literatürde şelale (waterfall) modeli olarak geçmektedir. Şelale modeli; analiz, tasarım, geliştirme, test ve uygulamadan oluşan beş aşamayı kapsamaktadır. Bir aşama bitmeden diğerine geçilememektedir ${ }^{10}$. Bu model, tasarım ve geliştirme sürecine verdiği önem ile öngörülebilir olması nedeniyle genellikle büyük çaplı ve karmaşı projelerde kullanılmaktadır. ${ }^{11} \mathrm{RAD}^{12}$ Proje Yönetimi, MS PPOJECT $^{13}$ ve PMBOK/PMI ${ }^{14}$ Proje Yaklaşımları Şelale Modeline göre tasarlanmıştır. ${ }^{15}$ Ancak Şelale Modelinin hiyerarşik ve bürokratik katılığı, müşteri odaklı esnekliğe elverişli olmaması ve pahalı olması nedenleriyle

etkinliği üzerinden öngörüler ortaya koyarak, projeye sermaye aktarmanın gerekliliği üzerinde verilecek karar destek sağlar (Planview, "Project Portfolio Management Defined", 2019, https://www. planview.com/resources/articles/project-portfolio-management-defined/, (Erişim Tarihi:21.03.2021).).

${ }^{10}$ C.G. Cobb, The Project Manager's Guide to Mastering Agile: Principles and Practices for an Adaptive Approach, John Wiley Sons., New Jersey, 2015.

11 Kai Petersen, Claes Wohlin ve Dejan Baca, "The Waterfal Model in Large-scale Development", In International Conference on Product-Focused Software Process Improvement, Springer, 2009, p. 328-338.

${ }^{12}$ RAD ingilizce "Rapid Application Development" kısaltılması olarak kullanılmaktadır. $\mathrm{Bu}$ proje yöntem süreci, sistemleri hızlı bir şekilde sağlama ihtiyacına cevap vermek için geliştirilmiştir. Hedeflerin iyi tanımlandığı ve dar bir odağının bulunduğu projelerde etkin olarak kullanılmaktadır.

${ }^{13}$ Aslında MS PROJECT'e bir yaklaşımdan ziyade proje yöneticisine süreçleri hızlı bir şekilde kontrol edebilme ve yönetebilme imkânı tanıyan bir yazılım olarak da bakmak gerekir.

${ }^{14}$ PMBOK ya da bilinen diğer adıyla PMI yaklaşımı, proje yönetimini iyi uygulama örnekleri üzerinden bir süreç mantığıyla belirleyerek çoğu projede uygulanabilir bir yol takibini hedeflemektedir (PMBOK ${ }^{\circledR}$ Guide, $A$ Guide to the Project Management, Body of Knowledge, Project Management Institute Sixth Edition, Pennsylvania, 2017).

${ }^{15}$ The PMI Guide to Business Analysis, Project Management Institute, Pennsylvania, 2017. 
Proje Yönetimine Kurumsal Bir Yaklaşım:

Jandarma Genel Komutanlığına Özgü Yeni Bir Proje Yönetim Modeli

küçük ölçekli projelerin yürütülmesinde verimli olamamaktadır. ${ }^{16} \mathrm{Bu}$ eksiklikler, çevik (agile) proje yönetim yaklaşımının gelişmesini tetiklemiştir. Çevik süreçler genellikle sık denetim ve adaptasyonu, ekip çalışmasını, kendi kendini örgütlemeyi ve hesap verebilirliği teşvik eden bir liderlik felsefesini, yüksek kaliteli yazılımların hızlı bir şekilde teslim edilmesini sağlamaya yönelik bir dizi mühendislik uygulamasını ihtiva etmektedir. ${ }^{17} \mathrm{Bu}$ yaklaşım tek bir yönteme sahip değildir. Projenin ihtiyacına, müşterinin beklentilerine ve anlık gelişen durumlara göre uygulanmasında farklılıklar barındırmaktadır. Proje ve yazılım geliştirme sürecinin küçük ve dinamik ekiplerle tasarımı ile yönetimi bu yaklaşımın temel özelliğidir. Yaygın uygulamaları; SCRUM Proje Yönetimi ${ }^{18}$ (Yazılım Sektöründe), PRINCE2 Proje Yönetimi, ${ }^{19}$ Extreme Proje Yönetimi, ${ }^{20}$ KANBAN Proje Yönetimi (Üretim Sektöründe) ${ }^{21}$ ve CMMI Yaklaşımıdır. ${ }^{22}$

Her ne kadar bahsi geçen proje yönetim yaklaşımları içerisinde sayılmasa ve doğrudan bir proje mantığı üzerinden oluşturulmamış olsa da Türk Silahlı Kuvvetlerinde ve Jandarma Genel Komutanlığının ${ }^{23}$ değişik

${ }^{16}$ C.G. Cobb, The Project Manager's Guide to Mastering Agile: Principles and Practices for an Adaptive Approach, John Wiley Sons, New Jersey, 2015.

${ }^{17}$ M.S. Merkow ve, L. Raghavan, Secure and Resilent Software Development, Taylor and Francis Group, Boca Raton, 2015.

18 SCRUM Proje Yönetimi kısa döngülerle çıktı üretmeye ve bunlardan alınan geribildirimleri temel almakta, öncelikle ana gereksinimlere odaklanarak ihtiyaca göre değişiklikleri yapmayı hedeflemektedir.

19 İngilizce "Projects in Controlled Environment"1n kısaltılmasını anlatan, sürece odaklanan ve bir projenin baştan sona kontrollü olarak başlatılması, devam edip sonlandırılmasını amaçlayan pratik bir proje yönetim metodudur.

${ }^{20}$ Extreme Proje Yönetimi (XP), müşterinin isteklerini küçük parçalar halinde ele alarak, en temel isteğine odaklanmayı, bu isteği gerçekleşirken de bozmadan sürekli test ederek müşteri kontrolünde ilerlemeyi hedefleyen bir yaklaşımdır.

${ }^{21}$ KANBAN Proje Yönetimi, işleyen sistemdeki sıkıntıları işlevsiz alanları ortaya çıkararak kalıcı çözümler üretmeyi amaçlayan bir yaklaşımdır.

${ }^{22}$ Ingilizce "Capability Maturity Model Integration” olan CMMI Yaklaşımı kurumlara süreçlerini iyileştirme için temel adımları çıkaran bir süreç iyileştirme yaklaşımıdır.

${ }^{23}$ Jandarma Genel Komutanlığ 668 sayılı KHK ile TSK bünyesinden çıkmış olsa da, geçmiş dönem uygulamalarının ve hali hazırda devam eden kurumsal kültürün bir yansıması olarak kavramsal olarak AKVES/KSİU kullanılmadan benzer süreçler işletilmeye devam etmektedir. Ayrıca, gerek 2803 sayılı Jandarma Teşkilat, Görev ve Yetkileri Kanunu gereği seferberlik ve savaş hallerinde askerî görevlerinin bulunması, 
seviyelerindeki birlik komutanları, kendilerine verilen kapsamlı görevlerin başarıldığından emin olmak için "Kıta Sevk ve İdare Usulü (KSİU)" ve üst seviyelere çıkıldığında "Askerî Karar Verme Süreci (AKVES)" ismi verilen sistematik bir yaklaşımı tatbik etmektedirler. ${ }^{24} \mathrm{Bu}$ usuller sayesinde komutan; zamanı, imkânları ve insan gücünü en verimli şekilde kullanmaktadır. $\mathrm{Bu}$ yöntemde, görevin niteliğine, zaman ve mekân faktörlerine göre usullerde sıra atlamak mümkündür. Tablo 1'de gösterilen AKVES daha çok üst seviyede kullanılan bir yaklaşımdır. . Operatif ve stratejik seviyedeki AKVES sürecinde aşamaların kapsamı ve içeriği rutin olmayan, daha karmaşık ve çok bileşenli, daha fazla durumsal farkındalık ve uyum gerektiren karalarla genişleyebilmektedir. ${ }^{25} \mathrm{Bu}$ doğrultuda şartlara ve ele alınan sürecin kapsamına bağlı olarak değişkenlik gösterebilmektedir.

\section{Tablo 1: Askerî Karar Verme Süreci}

\begin{tabular}{|c|c|c|}
\hline & \multicolumn{2}{|c|}{ Askerî Karar Verme Süreci } \\
\hline & Vazifenin Alınması ve Ön İnceleme & Hazırlıklara İlişkin \\
\hline \multirow{4}{*}{ 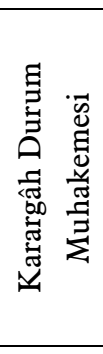 } & Vazifenin Tahlili & Ön Emrin Verilmesi \\
\hline & Ana fikrin Ortaya Konması & $\begin{array}{l}\text { Planlamaya İlişkin } \\
\text { Ön Emrin Verilmesi }\end{array}$ \\
\hline & Hareket Tarzlarının Belirlenmesi & \\
\hline & Komutanın Karar Vermesi & $\begin{array}{c}\text { Komutan Harekât Tasarısının } \\
\text { Ortaya Konması }\end{array}$ \\
\hline & Planın Tamamlanması & \\
\hline & Planın Onaylanması & \\
\hline & Planın Yayınlanması & \\
\hline & Planın Gözden Geçirilmesi & \\
\hline
\end{tabular}

gerekse hâlihazırda yürütülen görevlerde TSK unsurlarıyla birlikte hareket etmeleri, karar verme süreçlerinde kavramsal olmasa da süreç bazında bir birlikteliği gerekli kılmaktadır. ${ }^{24}$ Oğuzhan Pehlivan. ve Tolga Öz, "Askerî Karar Verme Sürecinin Taktik ve Operatif Seviyede Etkinliği ve Eğitim İhtiyacı”, Güvenlik Stratejileri Dergisi, 2020, 16(36), s. 954. ${ }^{25}$ Oğuzhan Pehlivan ve Tolga Öz, a.g.m., 2020, s. 961. 
Proje Yönetimine Kurumsal Bir Yaklaşım:

Jandarma Genel Komutanlığına Özgü Yeni Bir Proje Yönetim Modeli

AKVES'in ve taktik seviyede KSİU'nün temel ilkesi, alınan küçük bir vazifeden kapsamlı bir göreve kadar tüm işlerde uygulanabilir bir yol haritası çizmektir. Her projenin bir fikirle ve bunun gerçekleşmesi için bir irade beyanı ortaya konma ile başladığı düşünüldüğünde KSİU önemli bir yol haritası olabilmektedir. KSİU'daki safhalar Tablo 2'de gösterildiği üzere başlangıç ve tasarım aşamasında yapılacak işin tüm safhalarını ele alması açısından öngörülü, icra aşamasında ise durum ve şartlara göre uyarlanması gerektiğinde süreçlerde değişikliğe gidilmesi veya aşamaların gözden geçirilmesi açısından çevik proje yönetim süreçleriyle daha uyumlu olduğu değerlendirilmektedir. Jandarma Genel Komutanlığ özelinden hareketle mevcut proje yönetim dokümanlarının incelenmesi neticesinde; AKVES'in 2'nci aşamasından itibaren proje temelli üretim ve yönetim sürecinin tasarlanması ihtiyacı ortaya çıkmaktadır.

\section{Mevcut Durum}

Jandarma Genel Komutanlığında kurumsal ve bütüncül bakış1 gerektiren proje yönetim süreçleri bu maksatla oluşturulmuş bir yap1 üzerinden zayıf bir matris anlayış1 ${ }^{26}$ çerçevesinde işletilmektedir. Bunun yanında icracı birimlerde dâhil olmak diğer birimlerde ihtiyaçlar nispetinde projeler yürütülmektedirler. Proje başlangıcı bazen bir fikir üzerinden çıkabileceği gibi Jandarma Genel Komutanlığı gibi güvenlik politikaları alanın gereksinmeleri hızlı karşılanma ihtiyacı nedeniyle doğrudan bir direktif veya emirle de başlayabilmektedir. Bu noktada, projenin tespiti ve kabulü ön şartıyla çalışmaların başlaması gerekebilmektedir. Ancak başlangıç farklılı̆̆ söz konusu projeye ilişkin yeni fikirlerin gelişmesinin bir engeli olarak görülmemesi gerekmektedir. KSİU açısından ilk iki aşamanın karşılığı olan bu durum Jandarmanın zayıf matris yapısını statik doğasından dolayı örtemeyen öngörülü proje yaklaşımdan ziyade çevik proje yönetim yaklaşımına daha benzer bir özellik sergilemektedir. Mevcut durumda Jandarma Genel Komutanlığında proje yönetim süreç akış1 Şekil l'de gösterildiği gibidir.

${ }^{26}$ Zayıf matris yapı kavramıyla kastedilen Proje Yönetim Şube Müdürlüğü adında geçen yönetim fonksiyonunu yerine getirmekten ziyade farklı birimlerin yürüttügü projeler arasında koordinasyon sağlama misyonunu daha çok benimsemiş durumda olmasıdır. 
Erdem ERCIYES - Erdem ÖZGÜR

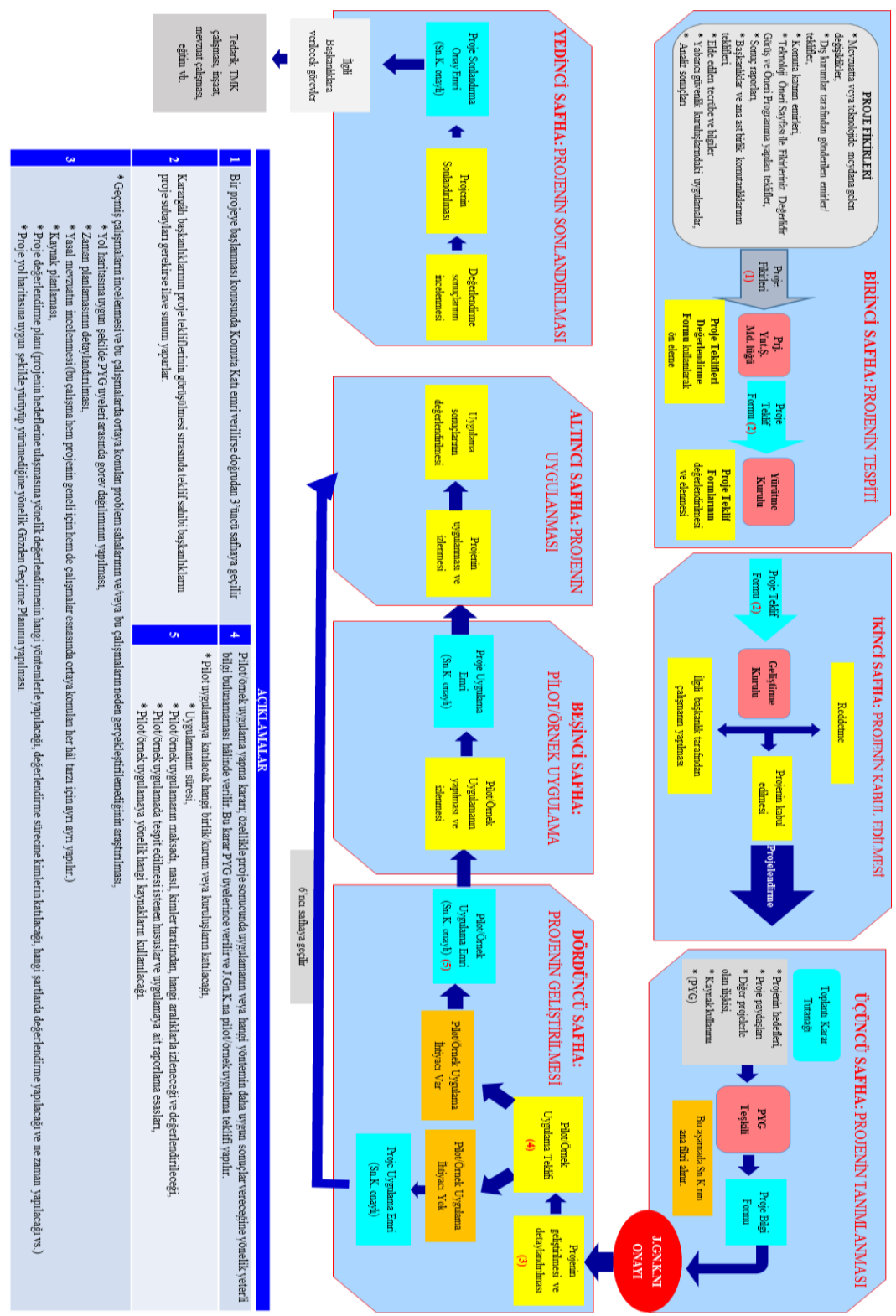

Şekil 1: Proje Üretim ve Yönetim Süreci ${ }^{27}$

${ }^{27}$ Yusuf Mutlu Genç, "Proje Üretim ve Yönetim Süreci”, Yayınlanmamış Bilgi Notu, 
Proje Yönetimine Kurumsal Bir Yaklaşım:

Jandarma Genel Komutanlığına Özgü Yeni Bir Proje Yönetim Modeli

Süreç projenin tespitiyle başlamaktadır. Bu safhada proje fikirleri toplanarak Proje Yönetim Şube Müdürlüğü tarafından ön elemeye tabi tutulmaktadır. Ön elemeyi geçen projeler hakkında ilgililerince proje teklif formları hazırlanmaktadır. Söz konusu proje teklif formları Proje Yürütme Kurulunda görüşülerek elemeye tabi tutulmaktadır. İkinci safhada proje teklifleri Geliştirme Kuruluna Sunulmakta ve projeler hakkında karar verilmektedir. Müteakiben proje tanımlama safhasına geçilmektedir. Bu safhada Proje Yönetim Grubu (PYG) teşkil edilmekte ve proje bilgi formları hazırlanmaktadır. Dördüncü safhada, projeler detaylandırılmakta ve proje uygulama emri hazırlanarak yayınlanmaktadır. Takip eden safhada pilot/örnek uygulamaya geçilmektedir. Pilot/Örnek uygulamanın başarılı olması durumunda proje uygulama emri yayınlanmaktadır. Altıncı safhada proje uygulanması takip edilerek uygulama sonuçları değerlendirilmektedir. Son aşamada değerlendirme sonuçları incelenmekte ve proje sonlandirılmaktadir.

Her ne kadar Şekil l'de bahsedilmemiş olsa da projelerin gerek kabul edilme gerekse sonrasındaki yürütülme aşamasındaki zaman ve kapsamla birlikte en önemli belirleyicilerden birisi bütçe kullanımıdır. Proje yönetim türüne göre bütçe faktörü esas itibariyle farklılık göstermemektedir. Jandarma Genel Komutanlığına Bütçe Kanunu ile ihtiyaçların temini ve tedariki maksadıyla tahsis edilen ödeneklerin işlemleri analitik bütçe sınıflandırılması doğrultusunda hazırlanan masraf planları çerçevesinde gerçekleştirilmektedir ${ }^{28}$.

\section{Araştırma Metodolojisi}

Jandarma Genel Komutanlığ 25.07.2016 tarih ve 668 sayılı Kanun Hükmünde Kararname ile İçişleri Bakanlığına tamamen bağlanmış olsa da kurumun sahip olduğu kültürel dinamiğin en temel yapı taşlarından olan sert hiyerarşik yapı ve sıkı disiplin anlayışı halen devam etmektedir. Jandarma, yaklaşık iki yüz yıllık geçmişiyle Türkiye'nin en köklü ve stratejik

Jandarma Genel Komutanlığı, Ankara, 2016, s. b-8/1-2.

${ }^{28}$ Jandarma Genel Komutanlığı ödenek kullanımı olarak mal ve hizmet alımlarında kullanılan başlıca mevzuat; 4734 Sayılı Kamu İhale Kanunu, 4735 Sayılı Kamu İhale Sözleşmeleri Kanunu, 5018 Sayılı Kamu Mali Yönetimi ve Kontrol Kanunu, 758 Sayılı Cumhurbaşkanlığı Kararı, İhale Uygulama Yönetmelikleri, JGY 310-6 (C) J.Gn.K.lığı Tedarik Yönergesi, JGY 310-7 J.Gn.K.lığı İstisnai Alımlar Yönergesidir. 
kamu kurumlarından birisidir. Bu köklü geçmiş, kurumun kültürünün oluşmasında ve yerleşmesinde önemli bir etki yaratmaktadır. Kurumun bürokratik kimliği nedeniyle proje yönetim sürecinde sözleşme ve anlaşmalar önceliklidir. Bununla birlikte, kırtasiyecilik sıklıkla görülmektedir. Süreç ve araçlar detaylı yazılı plan hale getirilmekte ve bu plana sadık kalınmaktadır. Çünkü görev değişimi gerçekleştiğinde projede devamlılık için plan gereklidir.

Etnografi, kültürel çalışmalarda gruplar ve kuruluşlar arasında meydana gelen sosyal etkileşimler, davranışlar ve algıların ortaya konulmasına yönelik bir araştırma metodolojisidir. ${ }^{29}$ Kurum kültürünün daha iyi anlaşılmasını sağladığı gibi nitel araştırma tasarımına kolayca uygulanabilmektedir. Yazarların yirmi yıldan fazla zamandır kurumda görev yapmaları ve kurumun büyük ölçekli çalışmalarında yer almalarından hareketle, çalışmanın Jandarma Genel Komutanlığına özgü bir proje yönetim yaklaşımı ortaya koyma hedefi de göz gönüne alındığında araştırma metodolojisi olarak etnografi benimsenmiştir.

$\mathrm{Bu}$ metodolojik yaklaşım sadece yazarların kültürel bakış açısı ve düşüncüleriyle sınırlı tutulmamış ve araştırma metodu olarak yarıyapılandırılmış mülakatlarla zenginleştirilmiştir. Mülakat sırasında araştırmacı ve katılımcı arasında oluşan karşılıklı etkileşim bilimsel araştırmalarda derinlikli bilgiye ulaşma noktasında fayda sağlamaktadır. ${ }^{30}$ Yarı yapılandırılmış görüşmelerde sabit sorular kullanılmaktadır, ancak araştırmacı görüşmenin akışına bağlı olarak farklı sorularda sorabilmektedir. $\mathrm{Bu}$ da bilgiye ulaşmada araştırmacıya esneklik sağlamaktadır. Bu nedenle çalışmada, mülakat türü olarak yarı yapılandırılmış mülakat tercih edilmiştir. Görüşme soruları hazırlanırken, etnografik kaygılar dikkate alınmış ve Jandarma Genel Komutanlığının kurumsal proje yönetim uygulamaları, kurum kültürü perspektifinde derinlemesine sorgulanmıştır. Jandarma Genel Komutanlığında halen aktif olarak proje yöneticiliği veya proje yürütücülügü yapan dokuz personel gönüllülük esasına göre mülakatlara katılmıştır. Katılımcıların beşi kadın dördü erkek olup yaş

\footnotetext{
${ }^{29}$ Metodoloji araştırmanın üst planıdır. Araştırma metodu ise metodolojinin gerçekleştirilmesi için belirlenen adımlardan birisidir.

${ }^{30}$ S. Kvale, Interview Views: An Introduction to Qualitative Research Interviewing. Sage Publications. Thousand Oaks, CA, 1996.
} 
Proje Yönetimine Kurumsal Bir Yaklaşım:

Jandarma Genel Komutanlığına Özgü Yeni Bir Proje Yönetim Modeli

aralığı otuz ve kırk beştir. Görüşme ortalama on dokuz dakika ve otuz saniye sürmüştür. Mülakatlar; araştırmacılar tarafından elle not almak suretiyle kaydedilmiştir. Katılımcılara görüşme yapmadan bir hafta önce araştırma protokolü gönderilerek çalışma ve sorulacak sorular hakkında bilgi verilmiştir. Bu protokolde, çalışmanın gönüllülük esasına dayalı olduğu, katılımcıların kimliğinin her ne sebeple olursa olsun açıklanmayacağı ve mülakat sırasında istedikleri zaman çalışmadan çekilebilecekleri özellikle vurgulanmıştır.

\section{Bulgular}

Katılımcılarla yapılan yarı yapılandırılmış mülakatlarda aşağıdaki sorulara cevaplar aranmıştır. Verilen cevaplar etnografik data içerik analiz yöntemi ${ }^{31}$ kullanılarak anlamlandırılmaya çalışılmıştır.

Soru 1: Ne kadar süredir proje yönetim faaliyetinde bulunuyorsunuz ve rolünüz nedir?

Katılımcıların üçü proje yöneticisi ve altısı proje yürütücüsü olarak proje faaliyetlerinde bulunmuştur. Katılımcıların üç ay ve on iki yıl arasında değişen ortalama olarak altı yıl süreli Jandarma Genel Komutanlığındaki proje yönetim süreci ile alakalı olarak tecrübeleri bulunmaktadır.

Soru 2: Daha önce proje yönetimine yönelik bir eğitim aldınız mı?

Proje yöneticilerin üçü, proje yönetimine yönelik bir eğitim almazken proje yürütücüsü olan dokuz kişi kısa süreli de olsa bir eğitim almıştır. Projenin başında olan ve projenin başarısında ana sorumluluğu taşıyan yöneticilerin proje odaklı bir eğitim almamalarını dikkat çekicidir.

Soru 3: Proje ve proje yönetimi kavramlarndan ne anliyorsunuz?

Katılımcıların proje ve proje yönetimi kavramlarıyla ilgili yaptıkları tanımlar aşağıda sıralanmıştır:

"Proje, yapılacak bir işte en yüksek verimle sonuca ulaşmak için, belirli metotlar çerçevesinde oluşturulmuş plandır. Yönetim ise bu planın sistemli

\footnotetext{
${ }^{31}$ Etnografik data içerik analiz yöntemi ilk olarak, kavram geliştirme ile tüm analitik süreç arasındaki dönüşümsel etkileşimleri belirleyerek iletişimi anlama ve teorik ilişkileri doğrulamaya odaklanmaktadır. Ortak noktaları bulmak, örüntüleri keşfetmek ve bulguları sınıflandırmak, bu nitel analiz yaklaşımının ana bileşenleridir (D.L. Altheide, Ethnographic Content Analysis, Qualitative Sociology, 1987, 10 (1), p. 65-77).
} 
bir şekilde ilerlemesi için kontrolünü, koordinesini sağlamak ve aşamalarnın takibini yapmaktır."

"Proje; bir amacı ya da ihtiyacı belirli bir sürede gerçekleştirmek ve özgün bir ürün ortaya çıkarmak için yapilan bir girişimdir. Proje yönetimi ise; projenin kapsam, süresi, maliyeti, paydaşlarn koordine ederek; projenin başaryya ulaşmasin sağlayacak planlama, takip ve sonuçlandirma süreçleridir.”

"Proje, ihtiyaç doğrultusunda amaç belirleyerek amaca ulaşmak için yapılan çalışmalardır. Projelerin planlama, yürütme ve değerlendirme aşamalarnın bütününe proje yönetimi denir."

"Proje, hali hazırda olmayan ve sisteme artı kazantm getirecek ürün ve düşüncelerdir. Proje yönetimi ise düşünce halinden ürün haline getirilinceye kadarki süreci yönetebilmektir."

"Proje, belirli bir amaca ulassmak için planl ve düzenli bir şekilde yapılan faaliyettir. Proje yönetimi ise projenin belirlenen amaca ve hedefe zamanında ulaşması için gerçekleştirilen sürecin yönetimidir."

"Proje; başlangıcı ve bitişi olan, ortaya bir ürün ya da hizmet koyan geçici bir faaliyettir.

Proje yönetimi; proje faaliyetleri sırasında, proje hedeflerine ulaşmak için kaynaklarn (insan, zaman, maliyet) planlanması, izlenmesi ve kontrol edilmesidir."

"Proje, içinde bulunulan kuruma yenilik getirecek, basslangicı ve sonucu belli bir sistemdir. Proje yönetimi ise bu sistemin başından sonuna kadar doğru çıktı alabilmesi için yapılan çalışmadır.”

"Proje bir amaç veya ürünün başarllabilmesi ya da ortaya çıkarlabilmesi için oluşan çalışma grubunun belirlenen zaman diliminde yaptı̆̆ çalışmalarn bütünüdür. Proje yönetimi ise bu sürecin bir sistem dâhilinde yönetilmesidir."

"Proje, ihtiyaç makamlarmmn isterleri doğrultusunda belirli bir süre içerisinde belirlenmiş bir ekiple belirli kaynaklar kullanarak bir ürün ortaya koymak için yürütülen süreçtir.

Proje yönetimi ise belirli bir projenin amaçlarna ulaşmast için zaman, maliyet gibi kaynaklarm organize edilerek hedefe en az hata ile ulaşılmasının sağlanmasıdır."

$\mathrm{Bu}$ tanımlardan görüleceği üzere proje faaliyeti tanımlanırken projenin temel özellikleri olarak; belirli bir amaca ulaşmayı hedefleyen planlı ve geçici bir faaliyet olması, özgün ve yeni bir ürün ortaya çıkarılması 
ve sınırlı kaynakları kullanması vurgulanmıştır. Proje yönetimi tanımında ise yönetimin temel faaliyetlerden olan plan, izlenme, takip ve kontrolden bahsedilmiştir.

Soru 4: Fandarma Genel Komutanllğında proje yürütülürken nasıl bir yönetim süreci belirleniyor ve uygulanıyor?

Jandarma Genel Komutanlığının dâhil olduğu proje süreçleri Şekil 2'de gösterilmektedir.

\section{Kurumsal Gelişim Projeleri}

Tedarik Projeleri

Savunma Sanayi Başkanlığı Projeleri

Avrupa Birliği Projeleri

TÜBİTAK Başkanlığı Projeleri

Şekil 2: Fandarma Genel Komutanlı̆̆ının dâhil olduğu proje süreçleri ${ }^{32}$

Yukarıda bahsedilen proje süreçlerinden kurumsal gelişim projeleri; Jandarma Genel Komutanlığının kendi imkân ve yetenekleriyle yürütülen projelerdir. Katılımcılara göre bu tür projelerin yönetiminde belli bir sistematik yaklaşım izlenmemektedir. İkiz görevle atanan proje yöneticisi tarafından zaman planlaması ve görev dağılımı yapılarak süreç yönetilmektedir. Projenin başarısı proje yöneticisinin yaratıcıllı̆ına ve yönetim kademesinin projeyi desteklemesine bağlıdır. Tedarik projeleri ise belirli mevzuata göre yönetildiği için kurumsal gelişim projelerine göre daha sistematik bir yaklaşıma sahiptir. Dış kaynaklı proje süreçlerinden Savunma Sanayi Başkanlığı Bütçe ve Projelerine; Jandarma Genel Komutanlığı olarak Ar-Ge aşamasında ihtiyaç sahibi veya izleyici olarak katılımda bulunulmaktadır. Ancak Jandarma bu projelerde yönetimsel

${ }^{32}$ Yazarlar tarafindan oluşturulmuştur. 
olarak söz sahibi olmamaktadır. ${ }^{33}$ D1ş kaynaklı proje süreçlerinden Savunma Sanayi Başkanlığı Projelerine; Jandarma Genel Komutanlığı olarak Ar-Ge aşamasında ihtiyaç sahibi veya izleyici olarak katılımda bulunulmaktadır. Ancak Jandarma bu projelerde yönetimsel olarak söz sahibi olmamaktadır. Avrupa Birliği ve TÜBİTAK kaynaklı projelerde de benzer bir süreç takip edilmekte ve bu kurumların proje süreçlerine ve uygulamalarına dâhil olunmaktadır.

Soru 5: Bulunduğunuz projelerde yer alan proje yöneticisi ve proje üyeleri nasıl seçiliyor?

Katılımcıların ikisi Avrupa Birliği proje ekiplerine personel seçerken sadece yabancı dil şartına bakıldığını, bir diğeri seçim süreciyle ilgili herhangi bir fikri olmadığını ifade etmiştir. Diğer altı katılımcı ise projelerin ikiz görevle yürütüldüğü, özel bir seçim yapılmadığını ve yönetici olarak en kıdemli kişinin proje yöneticisi olarak atandığını beyan etmişlerdir.

Soru 6: Fandarma Genel Komutanlı̆̆ında proje yönetim sürecinde proje yöneticisi ve proje üyelerinin rolleri nedir?

Katılımcılar proje yöneticisinin temel fonksiyonları olarak; ilgili birimler arasında koordinesini sağlamak, aşamalarını takip etmek, kurum adına ihtiyaçların yürütücü kuruma iletmek, projelerin etkin bir şekilde yürütülmesini sağlamak, kritik kararları almak olarak ifade edilmiştir. Öte yandan, proje üyelerinin rolleri ise; proje ilerleme toplantılarına katılım sağlamak, proje kapsamında icra edilen saha test ve değerlendirme faaliyetlerinde yer almak, kurum içerisinde kullanıcı birimlerin projeye yönelik farkındalığını sağlanmak ve sonucunda ürüne dönüşebilecek projelerde kullanıcı birimlerin yönlendirilmesi olarak sıralanmıştır.

Soru 7: Proje yöneticisi ve proje üyeleri projeleri asli işleri olarak $m \imath$ yürütüyorlar?

Katılımcılara göre; sadece Proje Yönetim ve Avrupa Birliği Şube Müdürlüklerinde görev yapan personel asli görevleri olarak proje faaliyetlerini yürütmektedir. Bu birimler dışındaki personel, proje işlerini asli görevlerini yanında ikiz görevli olarak yürütmektedir.

\footnotetext{
${ }^{33}$ Tolga Öz, “Savunma Harcamaları”, Ebru Caymaz ve Fahri Erenel, (ed.), Savunma Kaynaklarının Planlanması ve Yönetimi, Nobel Yayınları, Ankara, 2021, 249.
} 
Proje Yönetimine Kurumsal Bir Yaklaşım:

Jandarma Genel Komutanlığına Özgü Yeni Bir Proje Yönetim Modeli

Soru 8: Bulunduğunuz projelerde bütçe nasıl belirleniyor?

Projenin kaynağının türüne göre bütçe belirleme süreci farklılık göstermektedir. Bu kapsamda katılımcıların birisi süreci aşă̆ıdaki gibi özetlemiştir:

"Şimdiye kadar araștırma geliştirme projeleri için kurum tarafindan bütçe tahsisi olmamıştrr. Yürütülen Ar-Ge projelerinin kaynağı Savunma Sanayii Destekleme Fonu (SSDF) ve TÜBİTAK Kaynakl Ar-Ge (TÜKA) fonlarnndan sağlanmaktadır. Yeni başlanacak ve yürütücüsü $\mathcal{F}$.Gn.K.lığ olacak bir projede bütçenin kurum bütçesinden kullanılması için Mali Hizmetler Başkanlı̆̆ına talep gönderilmektedir.”

Kurum içerisinde yürütülecek projelerde projenin maliyeti belirlenirken, ihtiyaca yönelik piyasa araştırmaları kalem kalem emsal uygulamaları da göz önüne alınarak analiz ve modelleme yöntemlerinden de faydalanılarak gerçekçi, maliyet-etkin ve optimum bir bütçe ortaya konulmaktadır ${ }^{34}$. Katılımcılar, ayrıca kurumsal gelişim projelerinde; ihtiyaç ve süreç gerçekçi bir şekilde ortaya konulursa bütçe belirlemede herhangi bir sıkıntı olmadığını ve yeterli kaynă̆ın ayrıldığını ifade etmişlerdir.

Soru 9: Fandarma Genel Komutanlı̆̆ında icra edilen projelerde başarnlı olunuyor mu?

Bu soruya iki katılımcı fikrim yok şeklinde cevap vermiştir. Diğer katılımcıların kendi tecrübe ve görgülerine istinaden aşağıda görülen farklı görüşleri mevcuttur:

"Fandarma Genel Komutanliğını ihtiyaç makamı olduğu Ar-Ge projelerinde; projenin teknoloji haztrlk seviyesine (THS) göre başar oran değişmektedir. Örneğin mayın/EYP tespitine yönelik projelerde dünyada da bu konuda THS çok düşüktür. Bu nedenle ilk aşamada sonucunda bir ürün çıkmayacak ancak laboratuvar ortaminda geliştirilebilecek sistemler üzerinde geliştirme çalısmalar yapılmaktadrr. Büyük veri/derin öğrenme konularnnda yürütülen yazılim gelistirme projelerinde ise; kurum içi ihtiyacın karşllanabileceği ve sonucunda ürüne dönüsen projeler mevcuttur."

${ }^{34}$ Tolga Öz \& Ahmet Ergülen, "Secure and Optimum Fuel Distribution of NATO", Taylor E Francis Group Fournal of Applied Security Research, 2018, 13:2, p. 187, DOI: $10.1080 / 19361610.2017 .1354271$ 
“Genel olarak başarll oluyor.”

"Sonuçta evet ama süreçte hayrr."

"Yüzde 80'i başarlı oluyor."

"Genellikle projeler yarm kaliyor."

"Üst yönetimce sahiplendiği takdirde projeler başariya ulaşabilmektedir."

"Bazı projelerde başar sağlansa da genel olarak projeler sağllklı bir sekilde tamamlanamiyor."

Soru 10: Fandarma Genel Komutanlı̆̆nda proje yönetim faaliyeti icra edilirken başarısina etki eden iç ve diş faktörler nelerdir?

Katılımcıların cevaplarına istinaden proje yönetim faaliyetlerinin başarısına etki eden iç faktörler olarak; amirler, projede yer alan çalışanlar, bütçe, komuta katı, zaman, proje dışı görevler, ihtiyaç sahibi birimin projeyi desteklemesi, teknik destek sağlanması, projeyi yürüten birimin konuyla ilgili olması, proje yönetici ve yürütücülerin proje süresince görevde kalması; projede yer alan personelin alan bilgisi, karar alma sürecinin hızlı olması, yöneticilerin inisiyatif alması, personelin nicelik ve nitelik olarak yetersizliği; projeye konuyla ilgili kişilerin dâhil edilmesi, ilgili birimlerle iletişim ve koordinasyon, kurumsal kültür, projeye başlarken proje yöneticisinin yakın çevresi ve yatay hiyerarşinin yönlendirmeleri belirlenmiştir.

Diğer taraftan dış faktörler olarak; birlikte çalışılan diğer kurumların projeyi benimsemesi, ihtiyaç sahiplerinin sürekli projeye yeni olgular eklemek istemesi, mali kısıtlar, uluslararası ilişkililerdeki değişiklikler, paydaşlar, teknolojik yetersizlik, firmaların ürünlerini zamanında yetiştirememesi, projeyi ortaya çıkaran ihtiyaçların devam ediyor olması ve sahadan gelen ihtiyaç ve tecrübeler sıralanmıştır.

Soru 11: Fandarma Genel Komutanlı̆̆ına özgü proje yönetimi yaklaşımı nasil olmalıdır?

Katılımcıların verdikleri cevaplarda üzerinde durdukları temel konulardan birisi, proje ihtiyacının belirlenmesi sürecidir. Bu konuyla ilgili öne çıkan tespitler; proje ihtiyacı belirlenirken sahadaki personelden bildirim alınması, projelendirme kararının kişiye göre değil kurumun faydası gözetilerek verilmesi, ilgili tüm birimlerin görüşünün alınması, her şeye proje adı verilmemesi ve ihtiyacın proje olabilirliğinin bir kurul tarafından değerlendirilmesi olmuştur. 
Proje Yönetimine Kurumsal Bir Yaklaşım:

Jandarma Genel Komutanlığına Özgü Yeni Bir Proje Yönetim Modeli

Katılımcıların ortak olarak bahsettikleri basska bir husus da proje ihtiyacın tespiti, teşhisi ve tanımının yapılması ile başlayan süreci çözüm önerilerinin tespiti, modellenmesi ve raporlanmasını içeren bir diğer süreç ile takip edilmesidir. Bunun sağlanmasına yönelik olarak bir Ar-Ge merkezinin gerekliliği de vurgulanmıştır. Bu süreçte atılması gereken adımları katılımcılar aşağıdaki şekilde özetlemiştir:

"Bir proje fikrinin ortaya çıkmasından itibaren proje yönetim sürecinde yer alan kapsam, zaman, maliyet, kalite, kaynak, iletişim, risk, tedarik ve paydaş yönetimi aşamalarmn yürütülmesi için öncelikle proje özelinde "Proje Yürütme Grubu'nun oluşturulması, üst yöneticilerin ve ihtiyaç sahibi birimlerin desteği alınmalıdı (Kurum içerisinde ihtiyaç sahibi birimlerin de proje yürütmesi nedeniyle; yetkinin baska bir birime verilmesi çok tercih edilmemektedir. Bu nedenle doğrudan üst yönetime bağh bir birim olunmasi ya da projelerin tek bir birim tarafindan yürütülmesi bu durumu düzeltebilir.). Ayrıca, teknik isterler alanında uzman bir ekip tarafindan hazırlanmalıdır."

"Öncelikle proje başlangıç aşamasında, doğru planlama yapılmalıdır. Tüm faktörler (insan, makine, yazllım, para, zaman) net bir şekilde ortaya konulmal, hedefler gerçekçi olmalıdrr. Hedeften çok fazla sapma yaşanmaması için proje büyüklüğünün kabul edilebilir sinırlar içerisinde tutulması gerekir. Ayrica projenin risk faktörleri hesaplanmall, olası bir aksilikte yapılması gerekenler önceden bilinmelidir."

"Net bir hedef; gerçekçi ihtiyaç, net bir takvim; amaca ulaşmak için adımlar detayl belirlemek, bütçelendirme ve takvimlendirme; insan kaynă̆ yeterli sayıda olmasi sağlanmalıdır.”

"Projenin yürütülmesi Fandarma Genel Komutanlğ̆ bünyesinde oluşturulacak Ar-Ge birimi içerisinde bir çalışma grubu ve kurul tarafindan gerçekleştirilebilir. Bu safhada ilgili çalısma grubu tarafindan proje, $5 N 1 K$ sorularmin cevaplar, çözüm modeli, proje paydaşlar ve sorumluluklar vd. hususlar içerecek bir formatta hazırlanmalıdı. Ön kabulü yapılan projenin komutanllk ve/veya üst kurul onayn alınmasına müteakip $\mathrm{Ar}-\mathrm{Ge}$ birimi içerisinde proje grup/larnnca çalışmalarna başlanmalıdrr.”

"Düzenli aralıklarla sahadan bilgi akışı olmalı, görsel ve fiziksel olarak personelle beraber olunmal, Söz sizde tarzındaki problemler önemli, astlarm ihtiyaçlar doğrudan bildirmesi, proje ekibinin sahay kontrol etmesi ve bizzat olaylar yerinde incelemesi, mükâfat hususu sorunu 
düzgün bildirenden başlayarak emeği geçen herkesi kapsamall; bütçenin olması ve kullanılabilir olması lazım."

Katılımcılara göre proje yürütülmesinin son aşamasında ortaya ç1karılan ürünün test edilmesi ve takibi gerekmektedir. Proje sonucunda, pilot uygulama yapılarak ürün test edilmelidir. Ayrıca projelerin takibi için proje ofisleri kurulmalı, projenin bütün süreçlerini kapsayacak şekilde dokümantasyon yapılmalı ve ürün performansını takip amacıyla geliştirilmiş paket programlardan istifade edilmelidir.

\section{Yeni Bir Proje Yönetim Modeli}

Elde edilen bulguların yorumlanması neticesinde Jandarma Genel Komutanlığının proje yönetim sürecine özgülenebilecek Şekil 3'de gösterilen proje yönetim aşamaları oluşturulmuştur. $\mathrm{Bu}$ aşamalar hiyerarşik bir sıra takip etmektedir ve bir aşama bitmeden diğer bir aşamaya geçilememektedir.

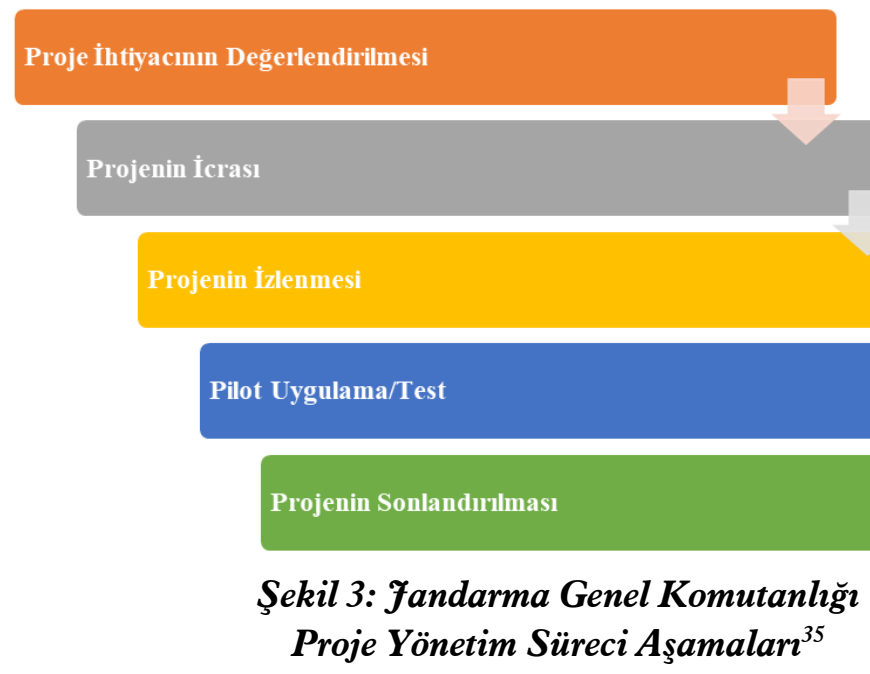

Modelin birinci aşaması, projenin gerçekten kurumun önemli bir ihtiyacını karşılayıp karşılamayacağının tespit edilmesidir. Bunun değerlendirilmesinin yapılması için projenin konusu itibariyle ilgili

\footnotetext{
${ }^{35}$ Yazarlar tarafindan oluşturulmuştur.
} 
Proje Yönetimine Kurumsal Bir Yaklaşım:

Jandarma Genel Komutanlığına Özgü Yeni Bir Proje Yönetim Modeli

birimlerden teşkil edilecek ve talep yöneticisinin başkanlık edeceği bir "Proje Değerlendirme Kurulu" oluşturulması gerekmektedir. Bu kurul marifetiyle ilgili birimlerden görüş alınmalı ve gelen görüşler nesnel esaslara dayanan bir yöntemle Kurulca değerlendirilmelidir. Müteakiben Kurul tarafindan, kapsam, zaman, maliyet, kaynak, risk, görev dağılımı, tedarik ve paydaş yönetimi aşamaları ile $5 \mathrm{~N} 1 \mathrm{~K}$ ( $\mathrm{Ne}$ ?, ne zaman?, nerede?, nasıl?, neden? ve kim? ) sorularına cevap verecek şekilde değerlendirme raporu hazırlanmalı ve Komuta Katına arz edilerek onayı alınmalıdır. Bu noktada belirlenen alt aşamalar ve yaklaşımlar PMI/PMP yaklaşımıyla benzerlik göstermekle birlikte bürokratik süreçlerin gerekliklerinde özelleşme söz konusudur. Bu yaklaşım Jandarma Genel Komutanlığının proje yönetim kültürünün temel taşlarından olan detaylı dokümantasyon ve süreç tanımlamayla da uyumludur. Proje ve yazılım geliştirme sürecinde ise kurumun bürokratik yapısından kaynaklanan statikliğin ve süreçlerin yavaş islemesinin önüne geçmek için küçük ve dinamik ekiplerle tasarımı konusunda Çevik Proje yaklaşım benimsenmelidir.

İkinci aşama projenin icrasıdır. Bu aşamada asli görevi projeyi yürütmek olan proje yöneticisinin başkanlığında bir proje grubu oluşturulmalıdır. Bu grup tarafından bütün proje süreci bir proje yönetimi yazılımına aktarılmalıdır. Proje grubu üyeleri sahadaki personelle irtibat halinde olmalı ve buradan sürekli bir bilgi akışı sağlanmalıdır. Ayrıca, proje grubu düzenli dönemlerde gelinen aşamayı ve yapılacak çalışmaları raporlamalidir.

Üçüncü aşamada projenin gelişimi takip edilmektedir. Proje grubundan farklı olarak projenin etki alanında olan birimlerin portföy yöneticilerinden oluşturulan "Proje İzleme Kurulu", proje grubunun periyodik raporlarını ve mevcut riskler göz önüne alınarak projenin kısa, orta ve uzun dönemli hedeflere ulaşmasını değerlendirmelidir. $\mathrm{Bu}$ değerlendirmenin çıktısı da raporlanmalı ve proje yönetim sistemine aktarılmalıdır. Üçüncü safhada ilk ikisinden farklı olarak dördüncü safha ile bir etkileşimi bulunmaktadır. Dördüncü safhada Proje Grubu tarafından yapılacak revize ve geliştirmelerin Proje İzleme Grubu tarafından dönem hedeflerine etkilerinin ortaya konması ve devaminda bunların tekrardan proje yönetim sistemine aktarılmasına ilişkin bir döngü kurulmalıdır. Genel olarak bu aşamada özellikle çevik proje yönetim yaklaşımının bakış açısı 
üzerinden hareket edilmekte ve ihtiyaçların yeterliliğinin değerlendirilmesi yanı sıra proje devamlılığının de irdelenmesi öngörülmektedir.

Dördüncü aşama pilot uygulama veya test safhasıdır. İhtiyaç olması halinde proje sonucunda elde edilen çıktının sahadaki uygulaması pilot bir çalışmayla test edilmelidir. Testin sonuçlarına göre projede gerekli düzeltme ve iyileştirmeler yapılmalıdır. Ancak bu aşamayı diğerlerinden ayıran nokta projenin tamamının tasarımı sonrası tek bir pilot uygulamadan ziyade ara aşamalarda ve ihtiyaca göre bu aşamaya geçilebilecek bir özellikte tasarlanmasıdır. Doğru ve uygulanabilir verilerle projenin devamlılığın sağlanması için ara hedeflere veya durumlara yönelik pilot uygulamalar öngörülebilmektedir. Yine bu aşamanın temel bakış açısı Çevik Proje Yönetimi Yaklaşımına benzerdir.

Beşinci aşamada proje sonlandırılmaktadır. Bu aşamada Projenin uygulanması sonrası hem ilgili birim tarafından hem de Proje İzleme Grubu tarafından uygulanama öncesinde belirlenen bir süre takip edilmeli, değerlendirilmeli ve sonuçlara göre proje geliştirme revize aşamasına geri dönülmeli ya da proje çıktıları hedefe ulaşmış ve uygulamaya istenen şekilde entegre edilmişse proje sonlandırılmalıdır. Projenin sonlandırılması ile proje kapsamında proje yönetim standartları ve yöntembilimine ilişkin geri beslemenin Proje Yönetim Şube Müdürlüğüne yapılması gerekmektedir. Oluşturulan modele ilişkin akış şeması Şekil 4'te sunulmuştur. 
Proje Yönetimine Kurumsal Bir Yaklaşım:

Jandarma Genel Komutanlığına Özgü Yeni Bir Proje Yönetim Modeli

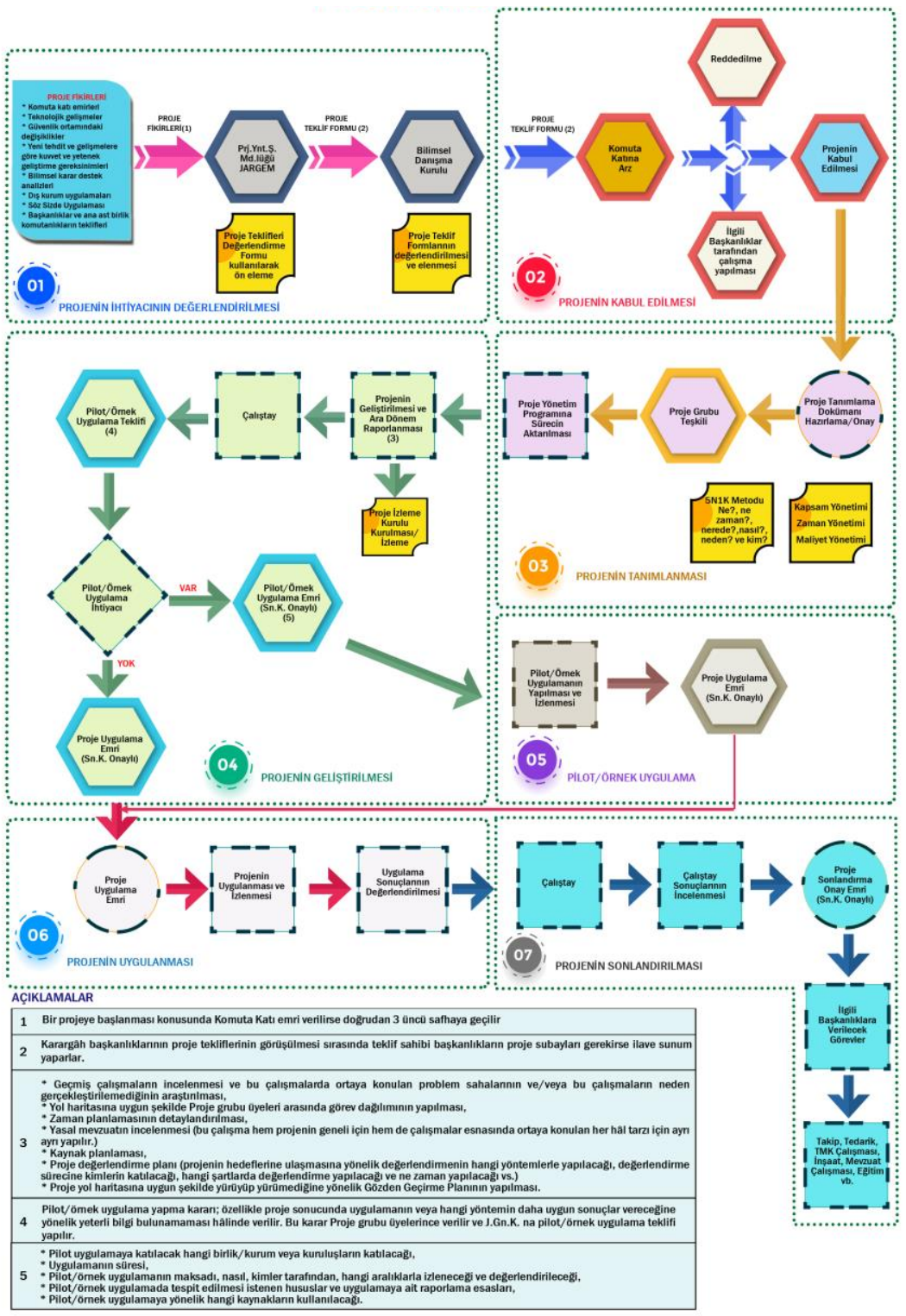

Şekil 4: Proje Yönetimi Akış Şeması ${ }^{36}$

${ }^{36}$ Yazarlar tarafindan oluşturulmuştur. 


\section{Sonuç Yerine}

Jandarma Genel Komutanlığı genel kolluk kuvveti olarak kamu düzeni ve güvenliğini sağlama sorumluluğunu yerine getirebilmek maksadıyla, halen devam görevlerinin yanı sıra gelecekte meydana gelmesi muhtemel gelişmeleri de dikkate alması gereği, proje geliştirme açısından daha sistemli, entegre ve bütünleyici bir yaklaşım sergileme ihtiyacını gerekli hale getirmektedir. $\mathrm{Bu}$ ihtiyacın giderilebilmesi için kurumsal gelişimini sağlayacak projelerin yönetim sürecini tanımlamak ve bu sürecin idare edilmesinde kullanılan kural ve yöntemleri birleştirmesi, uygulamada tam olarak sağlanamayan bütüncül bakışla gayret birliğini tesis etmesi önem kazanmaktadır.

Jandarma Genel Komutanlığının proje yönetim sisteminde etkinliğin sağlanabilmesi için atılması gereken en önemli adım; sistematik, bilimsel ve kuruma özgülenebilen bir proje yönetim yaklaşımı benimsemek olmalıdır. Bu anlayışın üst çatısını oluşturacak ve farklı projeler arasında eşgüdüm sağlayacak, sahaya yakın, ihtiyacı doğru olarak tanımlayabilen, proje yapan, yaptıran, yöneten, kontrol eden ve kendisine ait bütçesi olan bir Ar-Ge Merkezinin kurulması da kurum adına önemli bir gereklilik olarak ortaya çıkmaktadır. $\mathrm{Bu}$ merkez, farklı birimlerce ikiz görevle yürütülen bütün projeleri devralarak profesyonel ve nitelikli bir ekip ile proje yönetimi, araştırma, geliştirme ve üretim süreçlerini yönetmelidir. Ayrıca teknoloji ve yenilikleri yakından takip etmeli, kurumun gelecek öngörüsünü oluşturmalı, beklenmedik durumlara ve yeni tehditlere süratle adapte olabilecek kuvvet ve yetenekler geliştirmeli, ileri araştırma ve teknoloji yönetim sistemi oluşturmalı, önleyici kolluk anlayışını destekler yapay zekâ tabanlı yazılım ve sistemler geliştirmeli, projelerin etkili bir şekilde yürütülmesi ve izlenmesini sağlamalı, sahaya yakın, teknoloji ve ürün ihtiyacını doğru olarak tanımlayabilmeli, Savunma Sanayinin çalışmadığı alanlar ile sürpriz etkisi yaratabilecek, gelecek odaklı projelere yoğunlaşmalı, birlik teşkili ve proje ihtiyaç belirleme aşamasında yol haritası oluşturmalıdır. Teknolojinin yaşamı kolaylaştırıcı rolü, çok miktarda veriyi kısa bir süre içerisinde analizi yadsınamaz bir gerçek olmakla birlikte en son ve nihayetinde karar vericinin bu verileri doğru okuyabilmesi ve doğru tahlil edebilmesinin sezgisel zekâsı ile mümkün olacağı unutulmamalıdır. ${ }^{37}$

${ }^{37}$ Oğuzhan Pehlivan ve Tolga Öz., a.g.m., 2020, s. 959. 
Proje Yönetimine Kurumsal Bir Yaklaşım:

Jandarma Genel Komutanlığına Özgü Yeni Bir Proje Yönetim Modeli

Ayrıca bu merkez, milli teknolojinin gelişimime katkıda bulunmalı, kurumun ihtiyaç duyacağı araç, silah ve sistemlerin teknolojik üstünlüğe sahip olmasını sağlamalı, bilimsel karar destek sistemleri geliştirmeli, bilimsel analiz, modelleme ve simülasyon çalışmaları yapmalıdır. Böylelikle proje yönetim faaliyetlerinde süreç standartlaşması, paylaşım kolaylığı, organizasyon çapında sorumluluk, stratejik uyumun desteklenmesi, organizasyonel değer sunulması sağlanabilecektir.

Çalışmada elde edilen veriler doğrultusunda tasarlanan proje yönetim modelinde yaygın açıklanan iki yaklaşımın bir tekrarından ziyade kurumsal kültür ve mevzuat gereklilikleri nedeniyle özgün bir tasarım yapılması hedeflenmiştir. Bununla birlikte uygulaması yaygınlaşmış ve etkinliği kabul görmüş yöntemlerinden belirli aşamalarda faydalanılmıştır. Bununla birlikte uygulaması yaygınlaşmıs ve etkinliği kabul görmüş yöntemlerinden belirli aşamalarda faydalanıldığı da açıktır. Ayrıca kurum kültüründe önemli bir yeri olan diğer planlama modeli olan AKVES ile öngörülen proje yönetim modelinin ilişkili olması kurumsal kabulün daha hızlı olacağının bir göstergesidir (Tablo-2). Bu sayede hem Ar-Ge sistemi hem de söz konusu modelin etkinliğinin kısa sürede sağlanabileceği değerlendirilmektedir.

Tablo 2: AKVES ve Proje Yönetim Sistemi Modeli Karşılaştırması

\begin{tabular}{|c|c|c|c|}
\hline & $\begin{array}{l}\text { Vazifenin Alınması } \\
\text { ve Ön İnceleme }\end{array}$ & \multirow{3}{*}{$\begin{array}{l}\text { Birinci Safha: Proje } \\
\text { İhtiyaçlarının } \\
\text { Değerlendirilmesi }\end{array}$} & \multirow{4}{*}{$\begin{array}{l}\text { PMP/PMI } \\
\text { Proje } \\
\text { Yaklaşımı }\end{array}$} \\
\hline \multirow{4}{*}{ 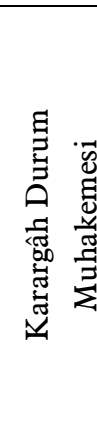 } & Vazifenin Tahlili & & \\
\hline & Ana fikrin Ortaya Konması & & \\
\hline & $\begin{array}{l}\text { Hareket Tarzlarının } \\
\text { Belirlenmesi }\end{array}$ & $\begin{array}{l}\text { İkinci Safha: Projenin İcrası } \\
\text { Üçüncü Safha: Projenin } \\
\text { İzlenmesi } \\
\text { Dördüncü Safha: Pilot } \\
\text { Uygulama/Test }\end{array}$ & \\
\hline & Komutanın Karar Vermesi & \multirow{5}{*}{$\begin{array}{l}\text { Beşinci Safha: Projenin } \\
\text { Uygulanması ve } \\
\text { Sonlandırılması }\end{array}$} & \multirow{5}{*}{$\begin{array}{c}\text { Çevik Proje } \\
\text { Yaklaşımı }\end{array}$} \\
\hline & Planın Tamamlanması & & \\
\hline & Planın Onaylanması & & \\
\hline 4 & Planın Yayınlanması & & \\
\hline 5 & Planın Gözden Geçirilmesi & & \\
\hline
\end{tabular}


Sonuç olarak Jandarmaya özgü geliştirilen yeni proje yönetim modelinin uygulanmasının projelerin başarıyla sonuçlanmasına olumlu etki edeceği düşünülmektedir. $\mathrm{Bu}$ bağlamda oluşturulacak bu Ar-Ge merkezinin ilk görevi de söz konusu proje yönetimi yaklaşımını kurumsal gereksinimlere uygun şekilde ilerler hale getirmek olmalıdır. Tüm bunlara ilave olarak Jandarma Genel Komutanlığında proje yönetim kültürü ve anlayışını sistematik ve bilimsel bir temele oturtmak için proje faaliyetlerinde çalışan personel sorumluluğuyla doğru orantılı olarak sistematik bir eğitim sürecine tabi tutulması gerekmektedir.

\section{Summary}

The project management model designed in accordance with the data obtained in the study is aimed to make an original contribution to the literature by developing a new authentic approach concerning specific needs and characteristics of the Turkish Gendarmerie General Command. This concern led to the result of utilizing ethnography methodology. Moreover, semi-structured interviews were conducted with the participation of nine gendarmerie personnel who are still actively working as project managers or project team members at the Gendarmerie General Command.

As a result of the interpretation of the findings obtained, a project management model of five stages has been created. These stages follow a hierarchical order and one stage cannot be passed before one stage ends. The first stage of the model is to determine whether the project will really meet an important need of the organization. The second stage is the execution of the project. In the third stage, the development of the project is followed. The fourth stage is the pilot implementation or testing phase. In the fifth stage, the project is finalized.

In order to institutionalize the project management culture and understanding on a systematic and scientific basis in the Gendarmerie General Command, the personnel who does project management activities should be subjected to a systematic training process in direct proportion to the responsibilities in the project management procedure. Finally, the most important step to be taken in order to ensure efficiency in the project management system of the Gendarmerie General Command is the 
Proje Yönetimine Kurumsal Bir Yaklaşım:

Jandarma Genel Komutanlığına Özgü Yeni Bir Proje Yönetim Modeli

establishment of a Research and Development Center. This center should take over all projects carried out with twin tasks by different units and manage project management, research, development and production processes with a professional and qualified team.

\section{Çatışma Beyanı:}

Araştırmanın yazarlar olarak herhangi bir çıkar çatışma beyanımız bulunmamaktadır.

\section{Destek ve Teşekkür Beyanı:}

Bu çalışmanin hazırlanmasında hiçbir dıs finansmandan yararlamilmamıstır. Çalışma sirasında verdiği destekten dolayı Fandarma Genel Komutanlı̆̆ına minnettarlğıтızı arz ederiz.

\section{Araştırmacıların Katkı Oranı Beyanı:}

Çalışmanın hazırlanmasında birinci yazarn katkı oranı \%60, ikinci yazarın katkı oranı \% 40 'ttr.

\section{KAYNAKÇA}

\section{Kitaplar}

COBB, C.G., The Project Manager's Guide to Mastering Agile: Principles and Practices for an Adaptive Approach, John Wiley Sons. New Jersey, 2015.

GENÇ, Y.M., Proje Üretim ve Yönetim Süreci, Yayınlanmamış Bilgi Notu, Jandarma Genel Komutanlığı, Ankara, 2016

KVALE, S. Interview Views: An Introduction to Qualitative Research Interviewing, Sage Publications. Thousand Oaks, CA: 1996.

LARSON, Eric W. \& GRAY, Clifford F. Project Management: The Managerial Process. McGraw-Hill Education, Sixth Edn. New York, 2014.

MERKOW, M.S. ve RAGHAVAN, L., Secure and Resilent Software Development. Taylor and Francis Group, Boca Raton, 2015.

PMBOK Guide, A Guide to the Project Management Body of Knowledge. Project Management Institute. Sixth Edition, Pennsylvania, 2017.

ÖZ, Tolga, "Savunma Harcamaları", Ebru CAYMAZ ve Fahri ERENEL, (ed.), Savunma Kaynaklarmin Planlanması ve Yönetimi, Nobel Yayınları, Ankara, 2021, 241-265.The PMI Guide to Business Analysis, Project Management Institute. Pennsylvania, 2017. 


\section{Makaleler}

ALTHEIDE, D.L. Ethnographic Content Analysis, Qualitative Sociology, 1987, 10 (1), 65-77.

ARTTO, K., Kujala, J., Dietrich, P., \& Martinsuo, M., 2008. What is project strategy? International Fournal of Project Management, 26 (1), 4-12.

AYGÜN, Salih and OZ, Tolga, "The Effects of Defence Expenditures on Growth: The Case of Turkey", Fournal of Defense Resources Management, 2020, 11(2 (21)), 5-23.

LENFLE, Sylvain. The Strategy of Parallel Approaches in Projects with Unforeseeable Uncertainty: the Mahhattan Case in Retrospect, International Fournal of Project Management, 2011, 29 (4), 359-373.

PEHLIVAN, Oğuzhan ve ÖZ, Tolga, "Askerî Karar Verme Sürecinin Taktik ve Operatif Seviyede Etkinliği ve Eğitim İhtiyacı”, Güvenlik Stratejileri Dergisi, 2020, 16(36), 947-975.

PETERSEN, Kai,, WOHLIN, Claes, BACA Dejan, The Waterfal Model in Large-scale Development, In International Conference on Product-Focused Software Process Improvement, Springer, 2019 s. 328-338.

REEVES, Scoot., KUPER Ayelet and HODGES Brian David, Qualitative research methodologies: ethnography, BMF, 2008, 337: 512-514.

İnternet Kaynakları

“1003-Öncelikli Alanlar Ar-Ge Projeleri Destekleme Programı Usul ve Esasları", https://www.tubitak.gov.tr/tubitak_content_files/mevzuat/esaslar/204BK-EK.pdf, Erişim Tarihi: 22 Mart 2021.

PLANVIEW, "Project Portfolio Management Defined", 2019, https://www.planview.com/resources/articles/project-portfolio-management-defined/, Erişim Tarihi: 21.03.2021.

ÖZ, Tolga \& ERGÜLEN Ahmet, "Secure and Optimum Fuel Distribution of NATO", Taylor E Francis Group Fournal of Applied Security Research, 2018, 13:2, 186-198, DOI: 10.1080/19361610.2017.1354271

WELLERSTEIN, Alex. "How many people worked on the Manhattan Project? Restiricted Data:" The Nuclear Secrecy Blog. http://blog.nuclear.secrecy.com/ 2013/11/01/many-people-worked-manhattan-project/. Erişim Tarihi: 31 Mart 2020.

\section{Mevzuat}

Türkiye Cumhuriyet 4734 Sayılı Kamu İhale Kanunu.

Türkiye Cumhuriyet 4735 Sayılı Kamu İhale Sözleşmeleri Kanunu.

Türkiye Cumhuriyet 5018 Sayılı Kamu Mali Yönetimi ve Kontrol Kanunu.

Türkiye Cumhuriyet 758 Sayılı Cumhurbaşkanlı̆̆ı Kararı.

Türkiye Cumhuriyet İhale Uygulama Yönetmelikleri.

MY 369-1 (C) Planlama, Programlama, Bütçeleme ve Uygulama Sistemi (PPBUS) Yönergesi. 